\title{
27. On the Great Depression Earthquakes of 701 in Tango and 1596 in Bungo'.
}

\author{
By Akitune Imamura, M. I. A.
}

(Comm. May 13, 1946.)

Introduction. While land deformations associated with destructive earthquakes in Japan consist, for the most part, of upheaval, tilting, or folding of land, there were two cases in whick the deformations consisted of mere subsidence exceeding 10 metres in vertical displacement and $100 \mathrm{sq.} \mathrm{km}$. in area, namely, the Tango earthquake of 701 and the Bungo earthquake of 1596. The former originated in Wakasa Bay, and the latter in Bungo Bay, each bay being a part of conspicuous depression zones in this country. It may therefore be said that the said earthquakes occurred, as seen from the distribution of stresses exerted against the Japan arc, on its tension side, whereas most destructive earthquakes occurred on its compression side.

The Bungo earthquake of 1596. This took place about one hour before the sunset on September 4. Fore-shocks occurred one after another since the beginning of the preceding month, the maximum frequency having been attained in the afternoon of that calamitous day. It then became quiet for about an hour. At about $17 \mathrm{~h}$, however, the calmness was suddenly broken by violent shakings accompanied by thunder-like roarings, thus causing destruction of houses and civil works particularly in the sothern littoral of Beppu Bay.

Beppu Bay, essentially an extension of Inland Sea, is an inlet in the north-eastern corncr of Kyūsyū Island. It is somewhat rectangular in shape, opening eastwards with an extent of $15 \mathrm{~km}$. from south to north, and $25 \mathrm{~km}$. from west to east. The city of Ooita is situated on the western part of its southern coast, while the spa city of Beppu occupies the southern littoral on the west of the bay.

There were, prior to the 1596 earthquake, two islands in the south-western corner of the bay, namely, Uryu-zima and Hisamitu-zima, the former lying on the east of the latter. Uryū-zima was about $4 \mathrm{~km}$. from west to east and $2.2 \mathrm{~km}$. from north to south, while Hisamitu-zima, which was, strictly speaking, a peninsula connected with the main land by a sand bar, was

1) Cf. full note in this Proceedings in Japanese language, 4 (1946), 369-384. 
about one-fourth in size of the former.

Uryū-zima, then inhabited by about 5,000 people, had a good harbour named Okinohama, which was frequently visited even by foreign vessels. The island received the brunt of the 1596 shock. Immediately after it had been devastated by the shakings, everyone in the island was amazed to find an extraordinary, untimely ebbing of the sea; eventually the straits were left dry, while to the east the sea-bed as deep as 10 metres was exposed to the air. The islanders, in fear of the invasion of tunamis, fled to the main land by craft or on foot, until at last what they had anticipated with a shuddering awe arrived at about $18 \mathrm{~h}$, thus overwhelming every thing on the island with victims of 708 lives. It is said that, of the inhabitants who were still staying in the island, only $7 \%$, i. e. about 50 , were rescued. Needless to say, the tunamis raged not only on the whole coast of Beppu Bay, but also in the bay next to the south, while untimely ebbing and flowing of the sea were observed even as far north-westwards as Simonoseki. In the next morning when the sea restored its ordinary calmness, only $20 \%$ of the island was visible above the sea. It is likely that later the sinking advanced still further sometimes in an acute manner, and then in a chronic, that which took place on September 10, the next year, being noteworthy for its haying brought the same fate to Hisamitu-zima. The former site of the two islands is now $60-74$ metres deep, the deepest place in the bay.

The phenomena so far mentioned would suggest that the epicentre, or more strictly, the seat of maximum depression, was situated to the east of Uyrü-zima at a distance of $8-16 \mathrm{~km}$. There is in the bay a deep zone which would have in the history of its formation a close relation with the catastrophe in question. This submarine trench, $4-8 \mathrm{~km}$. in width, runs from west to east close to the southern coast of the bay with the site of the sunken islands as its western terminus. While the bay is, for the most part, of the depth from 10 to 30 metres, the trench is $40-70$ metres deep. If the deposits, which had been carried there during the ensuing 350 years by such rivers as Oono-gawa and Ooita-gawa on the south and Yasaka-gawa on the north, were removed out of the bay, the trench should become much deeper possibly with another maximum depth near the assumed epicentre of the 1596 earthquake.

The Tango earthquake of 701. This took place in the night of May 12 in Wakasa Bay about $135^{\prime} 23 \mathrm{E}, 35^{\circ} 44^{\prime} \mathrm{N}$. Premonitory shocks occurred one after another for three days and nights until culmination was reached through considerable subsidence of land associated with tremendous tunamis, which 
flooded on the neighbouring coasts particularly in Kasa County. Close to the assumed epicentre are extant two small islets named Kamuri-zima (Oosima) and Kutu-zima (Ko-sima or Okino-sima), the former being situated about 4 $\mathrm{km}$. south of the latter. Prior to the 701 earthquake, these islets were mere peaks, respectively about 200 and 120 metres high, in a large island where flourished a village known by the name of Oosima, one of nine villages in Kasa County. It is said that the island disappeared in that very night, leaving only the two peaks together with the top of Tatigami-iwal) above the sea. It can be revealed from the present submarine topographic feature of the district that the former island of Oosima is now sleeping at the depth of 64 metres; it was possibly as long as $6.4 \mathrm{~km}$. from north to south with a width of $2.2 \mathrm{~km}$.

Concluding remarks. The two destructive earthquakes so far mentioned had characteristics similar which can be summarized as follows.

1) They furnished us of very rare examples of destructive earthquakes that occurred in the depression zones notorious in this country.

2) They were associated with subsidence of land as large as $60-70$ metres in vertical displacement and about $200 \mathrm{sq.} \mathrm{km}$. in area.

3) Tremendous tunamis raged on the neighbouring coasts.

4) They were preceded by conspicuous premonitory shocks.

5) After-shocks; which are common accompaniments to destructive earthquahes, were not recorded in the present cases. Whether this is due to missing of records or non-occurrence of any conspicuous after-shocks, is unknown; if the latter, it may be regarded as a characteristic possibly present in some of such destructive depression earthquakes.

6) It is likely that their occurrences had certain correlation with regional destructive earthquakes that occurred off the Pacific coast of Japan. That is to say, the Tango earthquake occurred 17 years later than the great tunami earthquake of 684, while the Bungo earthquake preceded that of 1605 by 8.5 years. It might be added that the great Tōkaidō earthquakes of 1854 were followed by the semi-destructive Inland earthquakes of 1854, 1857, and 1905.

On the other hand, there were some dissimilarities between the features manifested by the two earthquahes in question, a noteworthy being the present conditions of the drowned islands. It is likely that, while the former Kamuri-zima is still maintaining its original topographic feature under the

1) At present, a reef with its top about $80 \mathrm{~cm}$. deep. 
sea, Uryu-zima and Hisamitu-zima have dissolved, so to speak, intu the deep sea-bed. This would suggest that in the former case the subsidence occurred possibly as the result of block movement, whereas in the latter it occurred as the result of the formation of that gigantic submarine trench. 